\title{
MESOPHILIC AND THERMOPHILIC FILAMENTOUS FUNGI ISOLATED FROM PROCESSED OATS (Avena sativa L.) IN BRASIL
}

\author{
(Hongos filamentosos mesofilicos y termofilicos aislados de \\ avena procesada (Avena sativa L.) en Brasil)
}

\author{
Eliane Barbosa da Silva Nogueira \\ Maria Auxiladora de Queiroz Cavalcanti \\ Maria José dos Santos Fernandes \\ Departamento de Micología - Centro de Ciencias Biológicas \\ Universidade Federal de Pernambuco - 50670-420 - Recife - PE - Brasil
}

Palabras clave: Avena, hongos, mesófilos, termófilos. Key words: Oat, fungi, mesophilic, thermophilic.

\section{RESUMEN}

Con la finalidad de verificar la presencia de hongos filamentosos mesófilos y termófilos, se analizaron muestras de avena procesada envasada en: contenedores metálicos, caja de cartón y bolsas plásticas, ya sea en forma de escamas finas o gruesas, asi como en harinas. Lasmuestrasfueron procesadas mediante tres diluciones (1:10, 1:100, 1:100) y sembradas en placas de Petri en Agar Sabouraud $+C A F$, incubandose a 3 temperaturas: ambiente $28 \pm 2{ }^{\circ} \mathrm{C}, 45^{\circ} \mathrm{C}$ y $50^{\circ} \mathrm{C}$. Se aislaron un total de 48 taxa de hongos filamentosos, representados en 14 géneros.

Aspergillus y Penicillium, fueron los géneros más frecuentes, seguidos por Cladosporium, Rhizopus, Syncephalastrum, Curvularia, Acremonium, Nigrospora, Paecilomyces, Tritirachium, Sporothrix, Oidiodendron y un representante de los Aphyllophorales.

$A$ las temperatura de $45^{\circ} \mathrm{C}$ y $50^{\circ} \mathrm{C}$, se aislaron Aspergillus fumigatus, $A$. duricaulis, Rhizopus microsporus, $R$. oryzae, siendo A. fumigatus el que presentó un mayor número de aislamientos

\section{INTRODUCTION}

Oat (Avena sativa L.), has been worldwide produced for human and animal consumption, due to its great nutritive value and other digestive qualities (14).

The microbiota responsible for causing the wheat deterioration in food, specially in oats, corn, barley,

\section{SUMMARY}

In order to determine the occurrence of mesophilic and thermophilic filamentous fungi on processed oats, samples of powered, thin and thick oat flakes, kept in cans, cardboard boxes, and plastic bags were analysed. For each sample, 3 dilutions were prepared: $1: 10,1: 100,1: 1000$ and they were placed on Petri dishes with Sabouraud agar plus antibiotic and incubated at 3 temperatures, $28 \pm 2^{\circ} \mathrm{C}, 45^{\circ} \mathrm{C}$, and $50^{\circ} \mathrm{C}$. Forty eight taxa of filamentous fungi representing 14 genera were isolated, the most common being Aspergillus and Penicillium. Other genera recorded in order of their frequency were: Cladosporium, Rhizopus, Syncephalastrum, Alternaria, Curvularia, Acremonium, Nigrospora, Rhinocladiella, Paecilomyces, Tritirachium, Sporotrix, Oidiodendron and an unidentified representative of Aphyllophorales.

Aspergillus fumigatus, A. duricaulis, Rhizopus microsporus, and $\boldsymbol{R}$. oryzae were isolated at $45^{\circ} \mathrm{C}$ and $50^{\circ} \mathrm{C}$ temperatures. Among these, A. fumigatus was the most commonly found.

wheat, and rye, is greatly influenced by internal factors connected directly with the food, such as nutritive value, $\mathrm{pH}$, humidity, oxygen reduction potential, inhibitory compound, as well as by external factors like temperature, time of storage, relative humidity contained in the grain, insects, mechanical damage, and the presence and concentration of gases $(12,17)$. Among the contaminating microorganisms of food, fungi are responsible for the deterioration $(2,4)$. The aflatoxin, secondary metabolite 
produced by fungi, is also encountered in many food, such as soybean, corn, wheat, rye, oats, rice, among others (15). On the other hand, the occurrence of thermophilic and thermotolerant fungi in food has been the objective of taxonomic studies because of the great damage caused to processed foods (8).

In Brazil studies focused on the occurrence of fungi in grains and processed oats were poor. Consequently to support this, it was suggested to carry out research work on corn, barley, wheat and rice in grain according by Stenwing \& Liven (32) and Sauer et al (30) methodology.

The objectives of the present work were: the isolation and identification of filamentous fungi on processed oats, to determine the presence of mesophilic and thermophilic fungi, and the quality - quantity analysis of these fungi detected, considering the methods of processing and packing of the oat.

\section{MATERIAL AND METHODS}

The following processing and packaging of oats were utilized: thin and thick flaked oats in cardboard boxes and cans; powered oat in cardboard boxes; unrefined oat bran in cans and in plastic bags.

Samples were obtained in many supermarkets and selected those unopened and within the valid date for consumption. The thin and thick flaked oats in cardboard boxes and cans were obtained from two industries, the powered oat in cardboard boxes was obtained from three industries, and the unrefined oat bran in cans and plastic bags were obtained only from one industry. Thirteen samples were tested. The following culture media were used for isolation and identification of the fungi: Sabouraud agar plus yeast extract and $\operatorname{CAF}(0,100 \mathrm{~g} / \mathrm{l})$, Potato dextrose agar, Czapek agar, Oat agar, and Malt extract agar (20). The Warcup method (33), modified isolation technique based on diluition method was used to isolate fungi in one gram of each oat. Sample was ascptically weighted and diluted in $10 \mathrm{ml}$ of distilled sterilized suspension. From this diluted solution with concentration of $1: 100$ and $1: 1000$ were prepared. A $0,2 \mathrm{ml}$ sample of each dilution was plated in triplicate on Petri dishes in Sabouraud-yeast extract agar + CAF, and homogenize equally. Cultures were grown at three temperatures: in a $28{ }^{\circ} \mathrm{C}\left( \pm 2{ }^{\circ} \mathrm{C}\right)$ incubator room, or in a electric incubator at $45^{\circ} \mathrm{C}$, and $50^{\circ} \mathrm{C}$, for an up to seven day period. After 72 hours processed fungal colonies were counted and different isolates were transferred to specific culture media used for the corresponding groups of fungi.

Identifications were made with macroscopic and microscopic observations of the isolates. Microscopic observation was based in the morphological analysis of the structures using, when necessary, the Riddell (28) slide culture technique. Identifications were made with the use of a number of keys and manuals $(11,13,25,26$, 27).

Each fungi isolates at $45^{\circ} \mathrm{C}$ and $50^{\circ} \mathrm{C}$ were inoculated on potato dextrose agar and incubated $a t 45^{\circ} \mathrm{C}$ and $50^{\circ} \mathrm{C}$ for seven days.

The species isolated were storaged in the Micotheca URM, of the Mycology Department of the Biological Center of Science (CCB), at the Federal University of the Pernambuco (UFPE).

\section{RESULTS AND DISCUSSION}

In the analysis of 13 samples, a total of 282 colonies representative of 48 taxa of filamentous fungi distributed in 14 genera were isolated. The most frequent genera were Aspergillus $45,40 \%$. and Penicillium 24,11\%, Cladosporium 11,34\%, Rhizopus 5,68\% (Tabla 1). Other interesting taxa of smaller occurrence such as Nigrospora, Rinocladiella, Paecilomyces, Tritirachium, Sporotrix, Oidiodendron, and one representative of Aphyllophorales were also isolated (Table 1.) Among the most frequent species it can be mentioned: Aspergillus fumigatus, A. parasiticus, $A$. niveus, $A$. sydowi, and Penicillium implicatum (Table 1).

A total of 30 colonies of termophilic and thermotolerant fungi in three genera and five species. represented the $10,64 \%$ of total fungi isolated, where $A$. fumigatus was the most frecuent (Table 2).

Christensen \& Kaufmann (4), classified the fungi that contaminated grains of agricultural products, based upon their moisture requirements and their predominance in the fields and in storage. The storaged fungi occur predominantly in grains that have 13 to $18 \%$ of moisture and belong mainly to the genera Aspergillus and Penicillium. From the analysed samples, the predominant genera were Aspergillus, specially in powered oat packed in cardboard and Penicillium from thin oat flakes and flour packed in cans and cardboards. From those, the most common species were $A$. fumigatus and $P$. implicatum. Cladosporium spp. and Alternaria alternata, although isolated with less frecuency, were also obseved by Christensen \& Kaufmann ( $t$ ), who referred to them as "storage fungi". In relation to the occurrence of the $A$. fumigatus in the sample from processed oats, this species is referred to as pathogenic for men and animals by Lacaz (20), Rippon (29); Conant (6). Know-Chung \& Bennett (19).

Within the isolated species, there are some of them bearing potential abilities to produce micotoxins in food, mainly $A$. flavus and A.parasiticus. The former was isolated just once while the latter (6\% of the isolates), a 
Table 1. Filamentous fungi isolated from processed oats packed under different conditions

\begin{tabular}{|c|c|c|c|c|c|c|c|c|}
\hline Genera/species & Ff $c x$ & Ff It & Fg cx & Fg It & Farsp & Far It & Fh cx & Total \\
\hline Acremonium fusidioides (Nicot) W. Gams & 3 & & & & & & & 3 \\
\hline A. griseoviride (Onions \& Barron) W. Gams & & 1 & & & & & & 1 \\
\hline Alternaria alternata (Fr.) Keissi & & & & & & & 6 & 6 \\
\hline Aspergillus aureolatus Munt & & & 1 & 1 & & & & 2 \\
\hline A. brevipes Smith & & & & & & 3 & & 3 \\
\hline A. caesiellus Saito & & & & & 7 & & & 7 \\
\hline A. duricaulis Rapper \& Fennell & & & & 1 & & & 4 & 5 \\
\hline A. flavus Link & & & & & & 1 & & 1 \\
\hline A. fumigatus Fres. & & 4 & 4 & 16 & & 1 & 14 & 39 \\
\hline A. janus Rapper \& Thom & & & & & 4 & & & 4 \\
\hline A. janus var. brevis Rapper \& Thom & & & & & 4 & & 5 & 9 \\
\hline A. niveus Blochwitz & & & & 16 & & & & 16 \\
\hline A. parasiticus Speare & 3 & 3 & & & & 4 & 8 & 18 \\
\hline A. sydowii Bain. \& Sarf. & 4 & & & & 4 & & 6 & 14 \\
\hline A. terreus Thom & & 3 & & 3 & & & & 6 \\
\hline A. variabilis Gasperine & 1 & & & & & & & 1 \\
\hline Basidiomycete (Aphyllophorales) & 1 & & & & & & & 1 \\
\hline Cladosporium cladosporioides (Fres.) de Vries & 10 & & & & & & 1 & 11 \\
\hline C. oxysporum Berk. \& Curt. & 14 & & 8 & 2 & & 1 & & 25 \\
\hline C. sphaerospermum Pens. & 1 & & & & 1 & & & 2 \\
\hline C. tenuissimum Cooke & & & & & 1 & & & 1 \\
\hline Curvularia pallescens Boedjin & 5 & & & 1 & & & & 6 \\
\hline Eupenicillium sp. Ludwig & & & & & & 2 & & 2 \\
\hline Eurotium chevalieri Mangin & & & & & & 1 & & 1 \\
\hline Nigrospora sphaerica (Sacc.) Mason & & 1 & & & & & & 1 \\
\hline Oidliodendron griseum Robak & & & & & 1 & & & 1 \\
\hline Paecilomyces lilacinus (Thom) Samson & 2 & & & & & & & 2 \\
\hline Penicillium aurantiogriseum Diercky & & & & & 3 & & 3 & 6 \\
\hline P. bilaii Chalabuda & & & & & & & 5 & 5 \\
\hline P. citrimum Thom & & 2 & 1 & & & 1 & & 4 \\
\hline P. corylophilum Durckx & 1 & & 1 & & & & & 2 \\
\hline P. decumbens Thom & 1 & & & 2 & & & & 3 \\
\hline P. expansum Link & & 1 & 1 & & & & & 2 \\
\hline P. funiculosum Thom & 2 & 3 & & & & & & 5 \\
\hline P. implicatum Biourge & 2 & 12 & & & & & & 14 \\
\hline P. islandicum Sopp & 1 & & 2 & 1 & & & & 4 \\
\hline P. janthinellum Biourge & & & 5 & & & & & 5 \\
\hline P. melinii Thom & & 1 & & & & & & 1 \\
\hline P. oxalicum Currie \& Thom & & & & & & & 1 & 1 \\
\hline P. pinophilum Hedgcock & & & & & & & 4 & 4 \\
\hline P. sclerotiorum Van Beyma & & & & & 1 & 2 & & 3 \\
\hline P. waksmanii Zaleski & & & & & & 1 & & 1 \\
\hline Rhinocladiella atrovirens Nannf. & & & & & 1 & & & 1 \\
\hline Rhizopus microsporus V. Tieghem & & & 3 & & & 1 & & 4 \\
\hline R. oryzae Went \& Prinsen Geerligs. & & 3 & & & & 1 & 1 & 5 \\
\hline Syncephalastrum racemosum Cohn ex. Schrot & & & 2 & 2 & & 1 & & 5 \\
\hline Sporothrix cyanescens (de Hoog) de Vries & & & & & & & 2 & 2 \\
\hline Tritirachium oryzae (Vicens)de Hoog & 17 & & & & & & & 17 \\
\hline Total & 68 & 34 & 28 & 45 & 27 & 20 & 60 & 282 \\
\hline
\end{tabular}

F $\mathbf{f} \mathbf{c x}=$ (Thin flaked oats in cardboard boxes). Ff lt = (Thin flaked oats in cans). Fg cx = (Thick flaked oats in cardboard boxes). Fg It $=$ (Thick flaked oats in cans $)$. Far It $=$ (Oat bran in cans $)$. Far $\mathbf{s p}=($ Oat bran in plastic bags $) . \mathbf{F h} \mathbf{~ c x}=($ Oats bran in cardboard boxes). 
TABLE 2 - Thermophilic fungi isolated from processed oats at $45^{\circ} \mathrm{C}$ and $50^{\circ} \mathrm{C}$. temperatures

\begin{tabular}{|c|c|c|c|c|c|c|c|c|}
\hline Genera/species & $\begin{array}{c}\text { Ff cx } \\
45^{\circ} 50^{\circ}\end{array}$ & $\begin{array}{c}\text { Ff It } \\
45^{\circ} 50^{\circ}\end{array}$ & $\begin{array}{c}F g \text { Cx } \\
45^{\circ} 50^{\circ}\end{array}$ & $\begin{array}{c}\text { Fg It } \\
45^{\circ} 50^{\circ}\end{array}$ & $\begin{array}{l}\text { Far sp } \\
45^{\circ} 50^{\circ}\end{array}$ & $\begin{array}{l}\text { Far It } \\
45^{\circ} 50^{\circ}\end{array}$ & $\begin{array}{l}\text { Fh cx } \\
45^{\circ} 50^{\circ}\end{array}$ & Total \\
\hline Aspergillus duricaulis & & & & & & & 11 & 2 \\
\hline A. fumigatus & & & 2 & & & 1 & $\begin{array}{ll}3 & 18\end{array}$ & 24 \\
\hline Rhizopus microsporus & 1 & & & & & 1 & & 2 \\
\hline R. oryzae & & & 2 & & & & & 2 \\
\hline Total & 1 & & 4 & & & 2 & 419 & 30 \\
\hline
\end{tabular}

$\mathbf{F f} \mathbf{c x}=($ Thin flaked oats in cardboard boxes $) . \mathbf{F f} \mathbf{I t}=($ Thin flaked oats in cans $) . \mathbf{F g} \mathbf{c x}=($ Thick flaked oats in cardboard boxes $)$. $\mathbf{F g} \mathbf{~ I t}=($ Thick flaked oats in cans $)$. Far $\mathbf{l t}=($ Oat bran in cans $)$. Far $\mathbf{s p}=($ Oat bran in plastic bags $)$. Fh $\mathbf{c x}=($ Oats bran in cardboard boxes).

closely related species, is also a greather producer of micotoxis, and the most strains producing $B$ an $\mathrm{G}$ aflatoxin, two compounds which are toxic for animals. Aflatoxin B1 is certainly acutely toxic for humans, and responsible for liver necrosis following chronic exposure, and mainly involved in human liver cancer, perhaps synergistically with hepatitis B virus $(9,10,21)$.

With regard to processed oats, the first step involves the improvement of the phase of sanitation, that consists in the removal of foreign materials, followed by a slow heating designed to reduce the moisture content of the grain until it remains at about $6 \%$ and to avoid fungal development.

The large number of fungi found in the various forms of packing, can be explained by the procedures connected to the last stage of the process of production. Johnson \&Peterson (18), state that oats do not receive an efficient sterilization, since they are exposed only to fast boiling and heating, and the flaked material is later ground into flour and then packed. This form of processing is easily susceptible to fungal contamination.

In relation to the type of packaging, it was observed that there was more contamination in cardboard boxes than in cans, which indicates that the material utilized for packaging may enable an increase of moisture and temperature enough to allow later germination of propagules existing in a latent stage. Since Aspergillus and Penicillium, classified as "storage fungi" occurred frequently in the samples of processed oats, it is possible to suggest that these were acquired during the storage period of the grain . This fact was observed by Christensen (5) who concluded that fungal propagules on the seed coat of cereals can remain dormant inside the grain and develop when proper conditions arise.

Most of the taxa isolated in this work were also observed by other researchers, in grains of oats, wheat, corn, and barley $(3,24,30,32)$. Some of the fungi isolated from these natural substrates are thermotolerant and thermophilic. Physiological and biochemical factors influence their thermophilic capacity allowing them to grow and reproduce effectively at high temperatures $(7,8)$. Thermophilic species detected in this work are commonly isolated from soil $(3,22)$, but were also found in wheat, barley, hay and bean leaves $(1,23,31)$.

\section{REFERENCES}

1 - Abdel-Hafez, S. I. I.(1982). Thermophilic and thermotolerant fungi in the desert soils of saudi Arabia. Mycopathologia 80:15-20

2 - Bullerman, L. B.(1987). The occurence and significance of molds and mold Grow Foods. Journal of Food Production 50: 896

3 - Caretta, G.; Del Frate, G.; Franca, P. D. et al. (1986). Studies on the ocurrence of Fungi in wheat-Fiedol. I. Mesophilic, Thermophilic and Keratinophilic fungi in soil. Boletin Micológico 3:55-70

4 - Christensen, C. M. \& Kaufmann, H. H.(1965). Deterioration of stored grains by fungi. Annual Review of phytopathology 3:69-85

5-Christensen, C. M. (1969). Influence of moisture content, temperature and time of storage upon invasion of rough rice by storage fungi. Phytopatology 59:145-148

6 - Conant, N. F.; Snith, D. T.; Baker, R. D. \& Callaway, J. L.(1971). Micologia $3^{a}$ Edic. Interamericana, México.

7 - Cooney, D. G. \& Emerson, R. (1964). Thermofilic fungi. San Francisco London: Ed. W. H. Fremann and company .

8 - Crisan, E. V. (1973) Current concepts of thermophilism and the thermophilic fungi. Mycologia 65:1171-1198

9.- Davis,N.\& Diener, V.L. (1983). Biology of Aspergillus flav'us and A.parasiticus, some characteristics of toxigenic and non toxigenic isolates 
of A.flavus and A.parasiticus. In: Diener et al. Eds. Aflatoxin and A.flavus in com. pp. 112

10.- Diener, V.L.\& Davis, N.D. (1969). Production of aflatoxin on peanut under controlled environments. J.Stored Production Res. 5:251-258

11 - Domsch, K. H., Gams, W., Anderson, T. H. (1980). Compendium of soil fungi. San Francisco: Academic Press.

12 - Evangelista, J. (1989). Tecnologia de alimentos. São Paulo: Livraria Atheneu editora.

13 - Ellis,M.B.(1971). Dematiaceus Hyphomycetes. England: Commonwealth Mycological Institute.

14 - FAO Production Yearbook.(1981). Rome: Food and agriculture organization, 35 .

15.- Hesseltine, C.W. (1974). Natural occurrence of mycotoxin in cereals. Mycopath. et Mycol. Appl. 53:141-153

16 - Jackson , L. K .\& Ciegler, A. (1978).Production and analysis of citrinin in com . Applied and Environmental Microbiology 36:408-41

17- Jay, J. M. (1981).Microhiologia modema de los alimentos. Espanha: Editorial Acribia Zaragosa.

18 - Johnson, A. H.\& Peterson, M. S. (1974). Enciclopedia of Food Tecnology. New York: The Avi Publishing Company, Inc. 2: 662-664

19 - Kwong-Chung, K. J. \& Bennett, M. D. (1992). Mycology Medical. Lea \& Febiger Philadelphia .

20 - Lacaz, C. S.; Porto, E.; Martin, J. E. C..(1991). Micologia médica: Fungos, Actinomycetes e Algas de interesse médico. 8 ed. SAVIER, São Paulo .

21.- Moss, M.O. (1996). Mycotoxins. Mycol. Res. 100:513-523

22 - Moubasher, A. H.; Abdel-Hafez, S. I. I.; Abdel-Fattan, H. M. et al. (1982).Fungi of wheat and brood-bean straw composts. Mycopathologia 78:169-176
23 - Mullinge, S. K. \& Apinis, A. E.(1969). Occurrence of thermophilous fungi in stored moist Barley grain. Trans. Br. mycol. Soc. 53:361-370

24 - Petters, H. I.; Flanning, B.; Austin, B. (1988). Quantitative and qualitative, studies of the microflora of barley malt production. Journal of Applaied Bacteriology 65:279-297

25 - Pitt, J. I. (1988).A laboratory guide to common Penicillium species. Australia Commonweulth Scientific, and Industrial Research Organization

26 - Raper, K. B. \& Fennell, D. I. (1965). The genus Aspergillus Malabar Florida: Robert e Krierger.

27 - _.......... \& Thom, C. (1949). A manual of the Penicillia. Baltimore: Williams and Wilkins .

28 - Ridell, R. W.(1950). Permanent stained mycological prepartion obttained by slide culture. Mycologia 42:265-270

29-Rippon, J. W.(1982). Medical Mycology: the pathogeni actinomycetes. 2 ed. W.B. Saunders Company, Philadelphia .

30 -Sauer, D. B.; Storey, C. L.; WVaker, D. E. (1984). Fungal populations in U.S. farm stored grain and their relationship to moisture, storage time, regions and insect infestation. Phytopathology 74:1050-1053

31 - Singh, S. \& Sandhu, D. K. (1986). Thermophilus fungi in Port Blair soils. Journal Botany. 64:1018-1026

32 - Stenwig, H. \& Liven, E. (1988). Mycological examination of improperly stored grain. Acta - Agricultural Scandinavica 38:199-205

33 - Warkup, J. H. (1950). The soil plate method for isolation of fungi from soil. London, Nature. 